\title{
ОРГАНИ ЗМІШАНОЇ КОМПЕТЕНЦІї ЯК СУБ'ЄКТИ ПРОТИДІЇ ОРГАНІЗОВАНІЙ ЗЛОЧИННОСТІ
}

Доченко О. С.

Стаття присвячена висвітленню однієї з актуальних проблем адміністративного права та управління - визначенню суб'єктів змішаної компетенції щодо забезпечення протидії організованій злочинності в Україні.

Звернута увага на відсутність чіткого визначення на законодавчому рівні суб'єктів протидії організованій злочинності. Автором систему суб'єктів протидії організованій злочинності за різними ознаками поділено на три категорії. Водночас запропонована стаття присвячена лише третій категорії суб'єктів протидії організованій злочинності - органам змішаної компетенції, які здійснюють протидію організованій злочинності в певній сфері під час виконання своїх основних функцій, і протидія організованій злочинності не $\epsilon$ їхнім основним завданням.

Звернута увага на недосконалість і застарілі положення Закону України «Про організаційно-правові основи боротьби з організованою злочинністю" і необхідність прийняття нового Закону України «Про протидію організованій злочинHOCMi».

Ключові слова: протидія організованій злочинності, суб'єкти змішаної компетенції протидії організованій злочинності.

Статья посвящена рассмотрению одной из актуальных проблем административного права и управления - определению субъектов смешанной компетенции по обеспечению противодействия организованной преступности в Украине.

Обращено внимание на отсутствие четкого определения на законодательном уровне субъектов противодействия организованной преступности. Автором система субъектов противодействия организованной преступности по разным признакам разделена на три категории. В то же время предложенная статья посвящена лишь тре тьей категории субъектов противодействия организованной преступности - органам смешанной компетенции, которые осуществляют противодействие организованной преступности при выполнении своих основных функций, и противодействие организованной преступности не является их основной задачей.

Обращено внимание на несовершенство и устаревшие положения Закона Украины «Об организационно-правовых основах борьбы с организованной преступностью» и необходимость принятия нового Закона Украины «О противодействии организованной преступности».

Ключевые слова: противодействие организованной преступности, субъекты смешанной компетенции противодействия организованной преступности.

The article focuses on one of the pressing problems of administrative law and management - the identification of mixed competence entities in order to combat organized crime in Ukraine, their tasks, functions, competencies and powers in these matters, the solution of which is important for the fight against organized crime.

Attention is drawn to the lack of a clear definition at the legislative level of the subjects of combating organized crime, which has penetrated into all spheres of public life, public administration, law enforcement and judicial bodies, local self-government bodies, which significantly influences the resolution of issues against it.

Taking into account the directions of combating organized crime, individual opinions of scientists, own experience, of the system of subjects of combating organized crime, according to different features, is divided into three categories by the author: 1) bodies of general competence that produce and ensure the implementation of the policy of combating organized crime; 2) bodies of direct (functional) competence, which are intended to implement measures to combat organized crime; 3) bodies of mixed competence that counteract organized crime in a particular area in the performance of their essential functions, but counteracting organized crime is not their primary concern.

At the same time, the proposed article focuses only on the third category of organized crime counterparts - bodies of mixed competence that combat organized crime in a particular area in the performance of their essential functions, and counteracting organized crime is not their primary concern.

The forms of participation of bodies of mixed competence in combating organized crime are considered.

Attention is drawn to the imperfection and obsolete provisions of the Law of Ukraine "On Organizational and Legal Basis of Combating Organized Crime", which is a deterrent in the fight against organized crime and the need to adopt a new Law of Ukraine "On Combating Organized Crime".

Key words: counteraction to the organized crime, subjects of the mixed competence of counteraction to the organized crime.

Постановка проблеми. Реформована система правоохоронних органів України із протидії організованій злочинності, незважаючи на вивчення і посилання на зарубіжний досвід, все ще залишається малоефективною, і багато в чому наявні проблеми не вирішені. На жаль, реформована правоохоронна система продовжує залишатися такою, що не відповідає міжнародним стандартам захисту прав людини, відмічається каральною спрямованістю, корупційними зв'язками, залежністю від владних осіб, дублюванням функцій між собою, громіздким центральним апаратом і розбалансованою структурою на місцях, незадовільним організаційно-правовим і кадровим забезпеченням їхньої діяльності та ін. Тому важливою передумовою ефективного механізму адміністративно-правового забезпечення протидії організованій злочинності $\epsilon$ створення дієвої системи уповноважених суб'єктів такої протидії, визначення чіткої мети і завдань їхньої діяльності, наділення необхідними повноваженнями і компетенцією, створення ефективної законодавчої бази та ін.

Слід відмітити, що тільки спеціально створені суб'єкти протидії організованій злочинності не зможуть, на жаль, забезпечити ефективну протидію організованій злочинності. До цієї діяльності потрібно залучати 
й інші державні органи так званої змішаної компетенції, які повинні здійснювати протидію організованій злочинності в певній сфері під час виконання своїх основних завдань і функцій, а протидія організованій злочинності не $\epsilon$ їхнім основним завданням.

Стан дослідження. Окремим питанням дослідження протидії організованій злочинності і діяльності суб'єктів такої протидії присвятили свої наукові праці Л.І. Аркуша, М.Г. Вербенський, О.В. Головкін, В.Л. Грохольский, О.О. Дульский, М.В. Корнієнко, О.В. Копан, Є.В. Курінний, Б.В. Лизогуб, О.Н. Литвак, В.І. Литвиненко, Є.І. Макаренко, Н.Є. Міняйло, С.С. Мірошниченко, Т.М. Міщенко, Є.В. Невмержицький, Г.П. ПожидаєВ, І.В. Пшеничний, Ю.Ю. Сорочик, О.Ю. Шостко та інші. Водночас сьогодні залишається дискусійним питання щодо участі у протидії організованій злочинності державних органів, які повинні і можуть здійснювати протидію організованій злочинності в певній сфері під час виконання своїх основних завдань і функцій, хоча протидія організованій злочинності не $\epsilon$ їхнім основним завданням.

Метою цієї статті $\epsilon$ визначення державних органів, перед якими на законодавчому рівні необхідно чітко визначити мету, завдання, функції, компетенцію та повноваження із протидії організованій злочинності в певній сфері під час виконання своїх основних завдань і функцій, хоча протидія організованій злочинності не $\epsilon$ їхнім основним завданням.

Виклад основного матеріалу. Думки науковців і практичних працівників щодо стану протидії організованій злочинності в Україні, виходячи із власного досвіду, ми поділили на три групи:

1) органи загальної компетенції, що виробляють і забезпечують реалізацію політики протидії організованій злочинності, до яких слід віднести державні органи, яким властиве управління (адміністрування) та контроль за всіма сферами суспільного життя. До таких суб'єктів віднесено: Верховну Раду України, Президента України, Кабінет Міністрів України, місцеві державні адміністрації та органи місцевого самоврядування;

2) органи галузевої (функціональної) компетенції, які покликані здійснювати протидію організованій злочинності: Національна поліція України, Служба безпеки України, Національне антикорупційне бюро України, прокуратура, Державне бюро розслідування;

3) органи змішаної компетенції, які здійснюють протидію організованій злочинності в певній сфері під час виконання своїх основних функцій, і протидія організованій злочинності не $є$ їхнім основним завданням. Як правило, вони залучаються до такої діяльності органами галузевої (функціональної) компетенції епізодично.

У запропонованій статті ми зупинимось лише на третій групі суб'єктів протидії організованій злочинності органах змішаної компетенції, які здійснюють протидію організованій злочинності в певній сфері під час виконання своїх основних функцій, і протидія організованій злочинності не $є$ їхнім основним завданням. Переконані, що від чіткості і повноти законодавчої визначеності участі цих органів у протидії організованій злочинності залежить і ефективність такої протидії.

До органів змішаної компетенції, перш за все, слід віднести окремі державні органи, які визначені в п. 3 ст. 5 Закону України «Про організаційно-правові основи боротьби з організованою злочинністю» [1] як органи, які беруть участь у боротьбі з організованою злочинністю. Зокрема, це:

1) органи доходів і зборів (така назва й досі визначена в зазначеному Законі, що свідчить про неналежну його якість. Цей орган існував з 2012 по 2014 роки, з 2014 по 2018 роки - Державна фіскальна служба України, а 18 грудня 2018 р. постановою КМУ № 1200 Державна фіскальна служба України реорганізована і утворено Державну податкову службу України та Державну митну службу України) [2];

2) Державна прикордонна служба України;

3) органи державного фінансового контролю (Рахункова палата, Міністерство фінансів України, Державне казначейство України, органи Державної контрольноревізійної служби України);

4) органи і установи виконання покарань та слідчі ізолятори;

5) розвідувальний орган Міністерства оборони України;

6) Служба зовнішньої розвідки України.

Слід зазначити, що окремі органи, які зазначені в п. 3 ст. 5 Закону України «Про організаційно-правові основи боротьби з організованою злочинністю» [1] як органи, які беруть участь у боротьбі з організованою злочинністю, зокрема: Національна поліція України, органи прокуратури, НАБУ - нами обґрунтовано віднесено до органів галузевої (функціональної) компетенції, які покликані (зобов'язані) здійснювати протидію організованій злочинності, виходячи із законодавчих актів, регламентуючих їхні завдання, функції, компетенцію і повноваження. До таких законодавчих актів слід віднести Закони України: «Про Національну поліцію» [3], «Про прокуратуру» [4], «Про Національне антикорупційне бюро України» [5] та інші нормативно-правові акти.

Водночас, на наш погляд, перелік органів, які беруть участь у протидії організованій злочинності, не може бути вичерпним. Виходячи з аналізу повноважень органів галузевої (функціональної) компетенції, вони можуть до протидії організованій злочинності залучати й інші органи, установи, незалежно від форм власності, громадські організації та окремих громадян.

Участь зазначених суб'єктів у протидії організованій злочинності може здійснюватися у двох основних формах.

Перша - законодавчо-зобов'язуюча, коли окремих суб'єктів законодавець зобов'язує вчиняти певні дії щодо надання допомоги у протидії організованій злочинності. У ст. 18 Закону України «Про організаційно-правові основи боротьби з організованою злочинністю» [1] визначаються обов'язки державних органів, що мають контрольні повноваження. Зокрема, Національний банк України, Антимонопольний комітет, Фонд державного майна, Державна податкова служба, Державна контрольно-ревізійна служба, митні органи України, а також інші державні органи, що мають право контролю за дотриманням організаціями і громадянами законодавства України, з метою боротьби з організованою злочинністю зобов'язані:

1) під час здійснення в межах своєї компетенції контрольних функцій з'ясовувати неправомірні дії організацій і громадян, що можуть свідчити про злочинну діяльність або створювати умови для такої діяльності;

2) передавати відповідним спеціальним органам із боротьби з організованою злочинністю одержувану 

та науково-методичне забезпечення

під час здійснення контрольних функцій і аналізу інформацію, що надходить, відомості, що можуть свідчити про організовану злочинну діяльність та використовуватися для виявлення, припинення і попередження такої діяльності.

Відповідно до ст. 5 Закону України «Про організаційно-правові основи боротьби з організованою злочинністю» [1] сьогодні єдиним спеціальним органом із боротьби з організованою злочинністю $є$ спеціальні підрозділи з боротьби з корупцією та організованою злочинністю Служби безпеки України. Крім того, далеко не вся інформація, яка може бути виявлена зазначеними суб'єктами, відноситься до компетенції і повноважень спеціальних підрозділів із боротьби з корупцією та організованою злочинністю Служби безпеки України. У такій ситуації виникає правова невизначеність щодо отримання, перевірки і реалізації інформації, яка надходить від державних органів, що мають контрольні повноваження;

3) за дорученням спеціальних органів із боротьби з організованою злочинністю проводити в межах своєї компетенції ревізії, перевірки та інші дії щодо контролю за дотриманням законодавства України організаціями і громадянами;

4) розробляти пропозиції щодо вдосконалення законодавства, спрямовані на усунення умов, що сприяють злочинній діяльності;

5) здійснювати інші заходи, передбачені цим Законом та іншими актами законодавства.

Органи доходів і зборів (сьогодні - Державна податкова служба України та Державна митна служба України) зобов'язані:

1) забезпечувати виявлення порушень законодавства про податки, збори, платежі та негайно повідомляти про це відповідні спеціальні підрозділи з боротьби з організованою злочинністю;

2) за дорученням спеціальних підрозділів із боротьби з організованою злочинністю проводити перевірку своєчасності надання і достовірності документів, пов'язаних із обчисленням сум платежів до бюджету, одержувати документи про платежі, що підлягають оплаті, та ті, що фактично надійшли в бюджет, здійснювати із цією метою входження в інформаційну систему, зв'язану з підприємництвом;

3) негайно повідомляти про всі випадки перереєстрації підприємства у зв'язку зі зміною власника, спеціальні підрозділи з боротьби з організованою злочинністю;

4) надавати необхідну допомогу під час проведення оперативно-розшукових заходів у зоні митного контролю;

5) за дорученням спеціальних органів із боротьби 3 організованою злочинністю проводити перевірку законності дій організацій і громадян, пов'язаних із переміщенням предметів і речовин через митний кордон, та здійснювати спільно з Національним банком України комплексний контроль за їхніми валютними операціями;

6) за дорученням спеціальних органів із боротьби 3 організованою злочинністю забезпечувати контрольовані поставки наркотичних і психотропних засобів, а також зброї та інших предметів, що використовуються організованими злочинними групами й угрупованнями з метою контрабанди [1].
Національний банк України з метою реалізації державної політики у сфері боротьби з організованою злочинністю зобов'язаний:

1) забезпечувати виявлення порушень законодавства з боку комерційних банків та інших підконтрольних Національному банку України підприємств, установ, організацій, які створюють умови для організованої злочинної діяльності, і притягнення винних до відповідальності;

2) встановлювати обсяги i форми звітності, яка подається Національному банку України, необхідні для виявлення організованої злочинної діяльності та умов, що йй сприяють;

3) попередньо інформувати спеціальні підрозділи з боротьби з організованою злочинністю про великомасштабні операції фізичних осіб (у розмірі понад сто мінімальних заробітних плат) чи юридичних осіб (у розмірі понад п'ять тисяч мінімальних заробітних плат), здійснені одноразово або протягом 30 діб;

4) за рішенням слідчого судді, суду припиняти фінансування та операції з рахунків клієнтів [1].

Державна прикордонна служба України сприяє спеціальним підрозділам Служби безпеки України і підрозділам органів Національної поліції у виявленні, припиненні та попередженні організованої злочинної діяльності, затриманні та притягненні до відповідальності їі учасників. Із цією метою Державна прикордонна служба України за дорученням спеціальних підрозділів із боротьби з організованою злочинністю Служби безпеки України, підрозділів Національної поліції та за наявності підстав, передбачених законами України, зобов'язана:

1) проводити перевірку і тимчасове вилучення документів у конкретних осіб, які прямують через державний кордон України;

2) не пропускати окремих осіб через державний кордон, здійснювати їх затримання в порядку, встановленому законом;

3) оглядати конкретні транспортні засоби і майно, що прямують через державний кордон України, і вилучати виявлені при цьому предмети та речовини, заборонені до вивезення і ввезення в Україну, та предмети контрабанди;

4) здійснювати дії щодо контролю і затримання українських та іноземних невійськових суден.

Слід відмітити, що в аналізованому Законі (ст. 5) [1] органами, які беруть участь у боротьбі з організованою злочинністю, також визначено: органи і установи виконання покарань та слідчі ізолятори; розвідувальний орган Міністерства оборони України; Службу зовнішньої розвідки України. Водночас завдання, функції, компетенція, повноваження, форми та методи їх участі в боротьбі з організованою злочинністю в законодавчому акті не визначено. На наш погляд, доцільно було б участь цих суб'єктів у протидії організованій злочинності визначити і конкретизувати в зазначеному Законі.

Другою формою участі різних суб'єктів у протидії організованій злочинності $\epsilon$ взаємодія, яка відбувається відповідно до законодавства, в межах компетенції і повноважень кожної із взаємодіючих сторін. Форми такої взаємодії можуть бути різними. Але ми не ставили завдання дослідження і висвітлення таких форм взаємодії в цій статті. 
Висновки. Підсумовуючи викладене, слід відмітити, що на сьогоднішньому етапі розвитку правоохоронної системи України ще не сформовано єдиного підходу і бачення щодо стратегії протидії організованій злочинності. Чинний Закон України «Про організаційно-правові основи боротьби з організованою злочинністю» [1] містить певні протиріччя, неточності і невідповідності стану справ сьогодення, фактично спрямований на регулювання діяльності і визначення адміністративно-правового статусу тільки одного суб'єкта протидії організованій злочинності - спеціальних підрозділів із боротьби з організованою злочинністю Служби безпеки України. Тому зазначений закон потребує суттєвого доопрацювання, а ще краще - прийняття з урахуванням реалій сьогодення і наукових розробок нового Закону України «Про протидію організованій злочинності в Україні», в якому б чітко визначалися: стратегічна мета і завдання протидії організованій злочинності, суб'єкти здійснення такої протидії, їхній правовий статус, форми і методи протидії організованій злочинності, більш чітке визначення залучення державних та інших органів до протидії організованій злочинності та інші питання.

\section{Література}

1. Про організаційно-правові основи боротьби з організованою злочинністю: Закон України від 30.06.1993 р. № 3341-XII. Відомості Верховної Ради України. 1993. № 35. СТ. 358.

2. Про утворення Державної податкової служби України та Державної митної служби України : постанова Кабінету Міністрів України від 18 грудня 2018 р. № 1200. URL : https: / / www.kmu.gov.ua/npas/pro-utvorennyaderzhavnoyi-podatkovoyi-sluzhbi-ukrayini-ta-derzhavnoyimitnoyi-sluzhbi-ukrayini.

3. Про Національну поліцію : Закон України від 02.07.2015 № 580-VIII. Відомості Верховної Ради (ВВР). 2015. № 40-41. Ст. 379.

4. Про прокуратуру : Закон України від 14.10.2014 р. № 1697-VII. Відомості Верховної Ради (ВВР). 2015. №2-3. Ст. 12.

5. Про Національне антикорупційне бюро України : Закон України від 14.10.2014 р. № 1698-VII. Відомості Верховної Ради (ВВР). 2014. № 47. Ст. 2051.

Доценко О. С., кандидат юридичних наук, доцент, професор кафедри публічного управління та адміністрування Національної академії внутрішніх справ 